залучити стороною по справі суб’єкта господарювання (контрагента), вимогою якого може бути визнання неправомірними дій Держказначейства щодо зарахування коштів на електронний рахунок іншого платника податків.

\title{
Література:
}

1. Податковий кодекс України : Закон України від 02.12.2010 p. № 2755-VI. URL: https://zakon.rada.gov.ua/laws/show/2755-17\#Text (дата звернення 28.02.2021).

2. Про затвердження порядку ведення Сдиного реєстру податкових накладних. : Постанова Кабінету Міністрів України від 29.12.2010 р. № 1246. URL: https://zakon.rada.gov.ua/laws/show/1246-2010-\%D0\% BF\#Text (дата звернення 28.02.2021).

3. Деякі питання електронного адміністрування податку на додану вартість: Постанова Кабінету Міністрів України від 16.10.2014 р. № 569. URL: https://zakon.rada.gov.ua/laws/show/569-2014-\%D0\%BF\#Text (дата звернення 28.02.2021).

4. Про затвердження форм та Порядку заповнення i подання податкової звітності з податку на додану вартість: Наказ Міністерства фінансів України від 28.01.2016 р. № 21. URL: https://zakon.rada.gov.ua/ laws/show/z0159-16\#Text (дата звернення 28.02.2021).

5. Загальнодоступний інформаційно-довідковий ресурс. URL: http:// zir.sfs.gov.ua/main/bz/view/?src=ques (дата звернення 28.02.2021).

DOI https://doi.org/10.30525/978-9934-26-074-2-36

\section{МІГРАЦІЙНИЙ КОНТРОЛЬ ЯК СПОСІБ ПРОТИДІЇ НЕЛЕГАЛЬНІЙ МІГРАЦІї}

\author{
Олефір В. I. \\ доктор юридичних наук, професор, \\ професор кафедри публічного права \\ Інституту управління і права \\ Національного юридичного університету імені Ярослава Мудрого \\ м. Київ, Украӥна \\ Шлях широкомасштабних реформ, обраний Україною 3 метою \\ розбудови незалежності, демократії та проєвропейського розвитку \\ обумовлює суттєву зміну управлінських відносин в державі, удоско- \\ налення правового регулювання.
}


Сучасна міграційна політика формується на принципово нових засадах державної політики, на верховенстві права і законності. Адже, ці основоположні принципи - ключовий вектор правової держави та громадянського суспільства для подолання негативних наслідків процесів міграції, що розвиваються стихійно, створення умов для безперешкодної реалізації прав мігрантів, забезпечення гуманного ставлення до осіб, які шукають захисту на території України. Вкрай необхідним для підвищення ефективності вищезазначеної діяльності $\epsilon$ прогнозування міграційних процесів та формування міграційної політики 3 урахуванням змін політичної та економічної ситуації, що можливо лише 3 застосуванням організаційно-правових способів протидії нелегальній міграції. Безперечно, питання правового регулювання міграційних процесів $є$ обов'язком кожної держави, проте його реалізація має здійснюватися не лише на національному рівні, а й з урахуванням міжнародних вимог. Для України це особливо актуально в умовах російської агресії та викликаних нею міграцій населення, трудових та освітніх міграцій. В контексті вищезазначеного, надзвичайно важливим $\epsilon$ ухвалення Урядом України у липні 2017 року Стратегії державної міграційної політики на період до 2025 рроку.

Україна, як і весь світ, зазнала нового виклику епідеміологічного характеру - пандемії світового масштабу - розповсюдження гострої респіраторної хвороби COVID-19, яка вразила передусім найбільш незахищені групи населення, до яких безпосередньо належать нелегальні мігранти, що суттєво актуалізувало реалізацію контрольно-пропускних функцій міграційного контролю. Погіршення ситуації вимагає посилення контролю та відповідальності за його здійснення.

Процес інтеграції України до спільноти європейських держав як рівноправної, демократичної, соціальної, правової держави потребує правового визначення сутності, місця, ролі та функцій державного контролю в системі державного адміністрування.

У 2000 році кількість мігрантів становила близько 173 млн осіб, а вже у 2019 році їх число сягнуло 272 мільйонів [2]

Суттєве збільшення мігрантів на 100 млн. людей пояснюється високим рівнем життя в розвинених європейських країнах і одночасним зубожінням більшості населення в країнах Центральної та Південно-Східної Азії, що зумовлює міграцію багатьох людей у пошуках кращої долі.

Історично склалося так, що Україна розташована на своєрідному перехресті торговельних шляхів. Через своє географічне положення вона одночасно перебуває в центрі міграційних потоків, а в даний час, по суті, 
вимушено відіграє роль своєрідної «буферної зони» між Західною Європою і третіми країнами.

У зв'язку з погіршенням ситуацій захворювання на COVID-19 країни ЄС вжили жорсткі заходи реагування на факти незаконної міграції, що спонукало південні та західні регіони України поступити аналогічно до Угорщини, Македонії, Сербії, Італії, Хорватії та Греції, які також стали транзитними пунктами для нелегалів. Активізація роботи Державної міграційної служби та Державної прикордонної служби України дозволила припинити фунціонування ряду злочинних угрупувань та затримати громадян Молдови (492), Росії (455), Азербайджану (350), Угорщини (248), Туреччини (146), Грузії (140), Румунії (134), Узбекистану (134), Білорусі (131), США (127) та Вірменії (114) при спробі нелегального перетину державного кордону [5].

Аналіз стану міграційних процесів, в якому опинилася Україна, дозволяє виділити дві основні групи чинників, що сприяють прибуттю, безконтрольному проживанню, пересуванню та збільшенню кількості нелегальних мігрантів в державі. До першої (зовнішньої) групи чинників належать: нестабільність соціально-політичної ситуації в країнахекспортерах нелегальних мігрантів; наслідки війн, збройні конфлікти, побічні ефекти внутрішньополітичної боротьби; добре налагоджена й організована практична і пропагандистська робота «торговців живим товаром».

До другої (внутрішньої) групи належать: зручне географічне розташування України у центрі Свропи, наявність суміжних держав, що мають кордони з країнами Західної Свропи; недосконалість законодавчої бази, що регулює імміграційні питання в Україні; неузгоджена $з$ державними і правоохоронними органами діяльність деяких навчальних закладів України та комерційних структур щодо навчання і працевлаштування іноземних громадян, що призвело до створення на території України великої колонії іноземців (передусім громадян КНР, Кореї, В’єтнаму, Нігерії, Афганістану, Індії).

Вказана проблема постійно загострюється у зв'язку із зростанням впливу на ці процеси організованих злочинних угруповань. Досвід зарубіжних країн у боротьбі з організованою злочинністю свідчить про те, що у світовій правоохоронній практиці нелегальна міграція пояснюється як загальновизнана форма організованої злочинної діяльності, протидія якій з боку відповідних національних структур набуває дедалі актуальнішого значення і характеру.

Необхідність контролю над нелегальною міграцією зумовлена загрозами, які вона приховує в собі. Неврегульована міграція призводить 
до поширення нетипових інфекційних захворювань, про що свідчить світова пандемія, спричинена вірусом COVID-19. Продовжують існувати організовані кримінальні угруповання, що спеціалізуються на контрабандному перевезенні людей. Корупція серед посадових осіб, створення «чорного ринку» фальшивих документів, житла, транспорту та інших послуг. Не завжди проходять безкарно протиправні дії правопорушників, що дозволяють їм заробляти великі кошти та уникати відповідальності. Так, зокрема, за даними Державної міграційної служби, 5 березня 2019 р. в Польщі затримано 13 поляків та 3 українців за підозрою в організації діяльності злочинної групи, що забезпечувала іноземців документами для перебування у СС . Також у Польщі затримали 4 осіб, підозрюваних тому, що за грошову винагороду в 20152018 роках вони реєстрували громадянам України запрошення, необхідні для отримання польської візи [5]

За даними Державної міграційної служби України, з 2014 р. по 2020p. було виявлено 52792 нелегальних мігранти [4]

\section{Динаміка нелегальної міграції [7].}

\begin{tabular}{|c|c|c|c|c|c|c|c|}
\hline рік & $\mathbf{2 0 2 0}$ & $\mathbf{2 0 1 9}$ & $\mathbf{2 0 1 8}$ & $\mathbf{2 0 1 7}$ & $\mathbf{2 0 1 6}$ & $\mathbf{2 0 1 5}$ & $\mathbf{2 0 1 4}$ \\
\hline $\begin{array}{c}\text { виявлено } \\
\text { нелегальних } \\
\text { мігрантів }\end{array}$ & 4197 & 12864 & 11194 & 9678 & 6390 & 5111 & 3518 \\
\hline
\end{tabular}

\begin{tabular}{|c|c|c|c|c|}
\hline рік & $\mathbf{1 9 9 9}$ & $\mathbf{1 9 9 8}$ & $\mathbf{1 9 9 7}$ & $\mathbf{1 9 9 6}$ \\
\hline $\begin{array}{c}\text { виявлено нелегальних } \\
\text { мігрантів }\end{array}$ & 25278 & 12646 & 9202 & 5110 \\
\hline
\end{tabular}

Порівняльний аналіз періодів після здобуття Україною незалежності та $з$ початку військової агресії на Сході свідчить, що динаміка коливань нелегальної міграції майже не змінилася, хоча на сьогодні у державі створена сучасні Державна міграційна та Державна прикордонна служби, які зобов'язані реалізовувати державну міграційну політику та національну безпеку, а в період, коли Україна знаходиться серед країн, в якій чи не найгірші показники захворюваності на COVID-19, убезпечувати населення від погіршення ситуації.

Варто наголосити, що покращення міграційного контролю, зокрема, стеження за міждержавними переміщеннями різних категорій населення, запобігання нелегальній міграції, боротьбі з міжнародною злочинністю, завчасного реагування на надзвичайні ситуації, в які завжди можуть потрапити іноземці, повідомлення від позивача про намір запросити до себе іноземця, інформування про біженців та «втікачів» від дискримінації і переслідувань, розкриваються його функції. 
Важливим засобом здійснення міграційного контролю є перепис населення. Проте він проводиться досить рідко, дані застарівають та не показують реальної ситуації. В Україні перепис населення було проведено 2001 року, а наступний має відбутися у 2023 році.

Сферу контролю за міграцією Європейська Комісія та уряд України визнали пріоритетною у відносинах України та ЄС. Динаміка розвитку відносин між Україною та ЄС у сфері полегшення людських контактів, відкриття спільного кордону для вільного руху осіб залежатиме від здатності України контролювати власні кордони і протидіяти явищам нелегальної міграції, торгівлі людьми, контрабанди, міжнародної організованої злочинності, особливо в період загострення агресії Російської Федерації на сході України. Тому, надзвичайно важливим аспектом $\epsilon$ приведення статистики міграції до міжнародних стандартів, гармонізації державної статистики з європейською, що дасть можливість взаємообміну інформацією, врахування показників міжнародної міграції для реального аналізу та вивчення ситуації з нелегальними мігрантами, вжиття необхідних заходів у боротьбі з цими явищами, моніторингу та вивчення міграційних процесів, формування державної політики та вдосконалення національного законодавства.

\section{Література:}

1. Олефір В.І. Адміністративно-правове регулювання протидії нелегальній міграції та торгівлі людьми: Монографія.-К.: Друкарня МВС України. 2004.-308 с

2. В. Чумак, Н. Шаповалова, П.Казьміркевич, Політика України у сфері контролю над нелегальною міграцією, Міжнародний центр перспективних досліджень, К.: 2006. -56с.

3. Міграційні процеси в сучасному світі: світовий, регіональний та національний виміри (понятійний апарат, концептуальні підходи, теорія та практика). Енциклопедія/ Упоряд. Ю.І.Римаренко; За редакцією Юрія Римаренка., Київ, Видавництво «Довіра», 1998 р.-912 с.

4. Державна міграційна служба, Показники діяльності ДМС за 2014-2020 pp., режим електронного доступу: https:/dmsu.gov.ua/diyalnist/ statistichni-dani/statistika-z-osnovnoj-diyalnosti.html

5. Моніторинг міграційної ситуації та змін у сфері управління міграцією та кордонами, Березень 2019 року, режим електронного доступу: https://dmsu.gov.ua/assets/files/migprocess/zvit_vypusk_ 2019_03.pdf

6. Моніторинг міграційної ситуації та змін у сфері управління міграцією та кордонами, режим електронного доступу: https://dmsu.gov.ua/assets/files/migprocess/zvit_vypusk_2018_november.PDF 
7. Аналітичні довідки МВС України за 1996-1999 pp. «Про стан роботи паспортної служби органів внутрішніх справ України по лінії контролю за перебуванням іноземців на території держави»

DOI https://doi.org/10.30525/978-9934-26-074-2-37

\title{
ДИНАМІЧНІСТЬ ПРИНЦИПІВ ТА МАКРОФУНКЦІЇ АДМІНІСТРАТИВНОГО СУДОЧИНСТВА
}

\author{
Остафійчук Л. А. \\ кандидат юридичних наук, \\ доиент кафедри процесуального права \\ Чернівецького національного університету імені Юрія Федьковича
} м. Чернівиі, Україна

Соціальне призначення i сутність права та адміністративного судочинства розкривається i конкретизується в їх принципах та функціях. Чи є ці принципи однаковими для права загалом, чи все ж таки кожна галузь права має свої особливі, притаманні лише їй принципи? Сучасний дослідник процесуального права В. М. Протасов зазначив, що «загальна теорія права в іiї сучасному стані індиферентна до різниці між матеріальним i процесуальним правом при оцінці правових явищ $\mathrm{i}$ більшою мірою іiі можна вважати «теорією матеріального права» [11, с. 18]. Проте, А. О. Павлушина слушно зауважила, що в рамках обговорюваної теорії не було належним чином враховано самостійну змістовну цінність норм процесуального права, тому що автори наполягали, що процесуальні норми є похідними від матеріальних [9, с. 31]. Далі виникла концепція судового права (1980 р.), яка мала б об'єднати кримінальний і цивільний процеси, а пізніше й судоустрій. Але, як показала практика розвитку галузевих наук, - цього не відбулося, та й не могло відбутися. Хоча, наприклад, - судова система і судочинство як країн загального права, так і держав, правосистема яких відноситься до континентальної правової сім'ї, будуються на розумінні високого ступеню спільності судових процедур, основою яких $\epsilon$ обов'язковий набір принципів i норм, які забезпечують конкретне положення особи в процесі. Крім цього, в конституціях більшості західних держав, загальні принципи i правила здійснення правосуддя визначені по відношенню до правосуддя в цілому, незалежно від конкретної процесуальної форми, особливості якої виражені в різних процесуальних кодексах [9, с. 38-40]. Отже в цій частині нашого 146 